\title{
Behavior of concrete beams reinforced with FRP during bending
}

\author{
Igor Gorbunov and Vladimir Kakusha ${ }^{*}$ \\ Moscow State University of Civil Engineering, Yaroslavskoe shosse, 26, Moscow, 129337, Russia
}

\begin{abstract}
Article describes methods and results of experimental research for strain behavior, crack formation and fracture of concrete beams reinforced with fiber reinforced polymer (FRP) bars during bending moment action. 18 beams $(3+3$ series $)$ reinforced with glass FRP (GFRP) and basalt (BFRP) 6, 10 and 14 $\mathrm{mm}$ in diameter were tested. Deflection in the middle of the beam, concrete and bars strain and ultrasonic transmission time for 4 routes were measured during tests besides visual inspection. Main crack formation occurred at $8-20 \%$ of the ultimate load for all beams. Crack formation was transition border to linear (elastic) straining at low bending stiffness. More than 15 times decrease in bending stiffness was seen for beam reinforced with two types of bars $6 \mathrm{~mm}$ in diameter compared to initial values. Existence of main cracks and major deflections is not allowed during design of bending elements. However small bending stiffness at linear elastic straining is a positive factor in case of «hard» loading and impact (pulsed) loading. It is possible to prevent structures collapse and people deaths at impact loading and cyclic «hard» loading by permitting crack formation in load bearing structures.
\end{abstract}

\section{Introduction}

Numerous Russian and foreign papers show high strength of bending concrete elements reinforced with FRP combined with low stiffness and cracking resistance [1-10], [13-16].

Regulatory documents establish requirements and conditions for beams with FRP testing [11],[12]. Requirements and design rules for concrete elements reinforced with FRP only apply to static loading. Contributions [17-18] show special aspects of dynamic loading of bending concrete elements and junctions with FRP. This research was set out to acquire data on stiffness, crack resistance, concrete and bars strain and strength of beams reinforced with GFRP and BFRP bars 6,10 and $14 \mathrm{~mm}$ in diameter. These beams were manufactured

*Corresponding author: kakushava@gmail.com 
from concrete class B30. Acquired data are regarded as benchmark for dynamic tests planning of similar beams reinforced with FRP bars.

\section{Methods and materials}

Beams were loaded on testing equipment rigged with reconfigurable loading frame CFM Schiller, hydraulic cylinders MTS 201.30T and controller FlexTest-60.

Deflections were measures using digital indicators Micron with measuring sensitivity of $0,01 \mathrm{~mm}$.

Cracking process was recorded using ultrasonic apparatus Pulsar 1.2 with piezoelectric transducers functioning at frequency of $65 \mathrm{kHz}$.

FPR bars and concrete stain was logged using multichannel measuring system NI PXIe1075. Strain gage with measurement base of $1 \mathrm{~mm}$ were mounted on FRP bars. Strain gages with measurement bases of 60 and $120 \mathrm{~mm}$ were mounted on concrete surface.

Figure 1 shows strain gages and ultrasonic transducers layout.

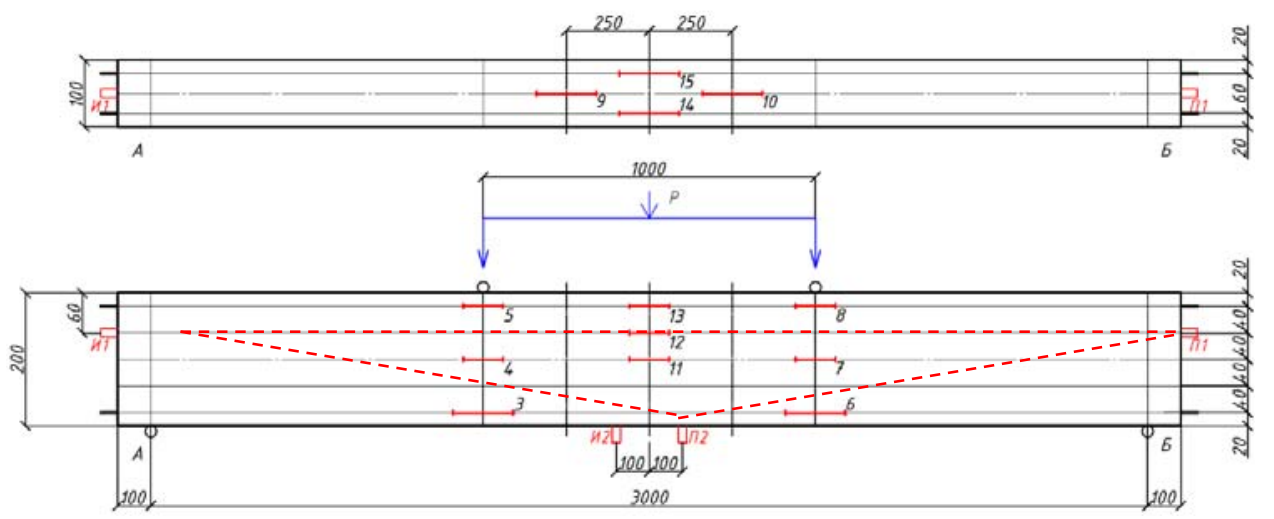

Fig. 1. Strain gages and ultrasonic transducers layout

Standard specimens for determination of concrete properties were tested on machine Instron $1000 \mathrm{HDX}$.

Crack formation process was also inspected using Brinell microscope MPB-2.

Beams loading was done in stages:

- before crack formation - stages of $1(0,5) \mathrm{kN}$ with a loading speed of $1,0 \mathrm{kN} / \mathrm{min}$ and load hold during 5 minutes at each stage;

- after crack formation - stages of 2,0-4,0 $\mathrm{kN}$ with a loading speed of $6,0 \mathrm{kN} / \mathrm{min}$ and load hold during 5 minutes at each stage;

Load and displacement of hydrocylinder, beam deflection, strain of strain gages, ultrasonic apparatus readings were recorded during holds. Visual inspection and crack formation process recording was done as well. Two couples of ultrasonic transducers allowed to monitor crack formation and growth.

\section{Test results}

Figure 2 and 3 show web of cracks that formed on a specific loading stage. Crack formation kinetics was estimated based on ultrasonic control data.

Sounding was carried out on two longitudal and symmetric oblique routes (figure 1). Cumulative information on crack formation in different areas of beams was acquired based on load-ultrasonic impulse transmitting time relation data. Typical pattern of concrete disruption for all beams is shown through ultrasonic control of beam reinforced with GFRP 
bars $\varnothing 6 \mathrm{~mm}$ (figures 4 and 5). All sounding routes show that growth intensity of formed main cracks decreases with increase in load.

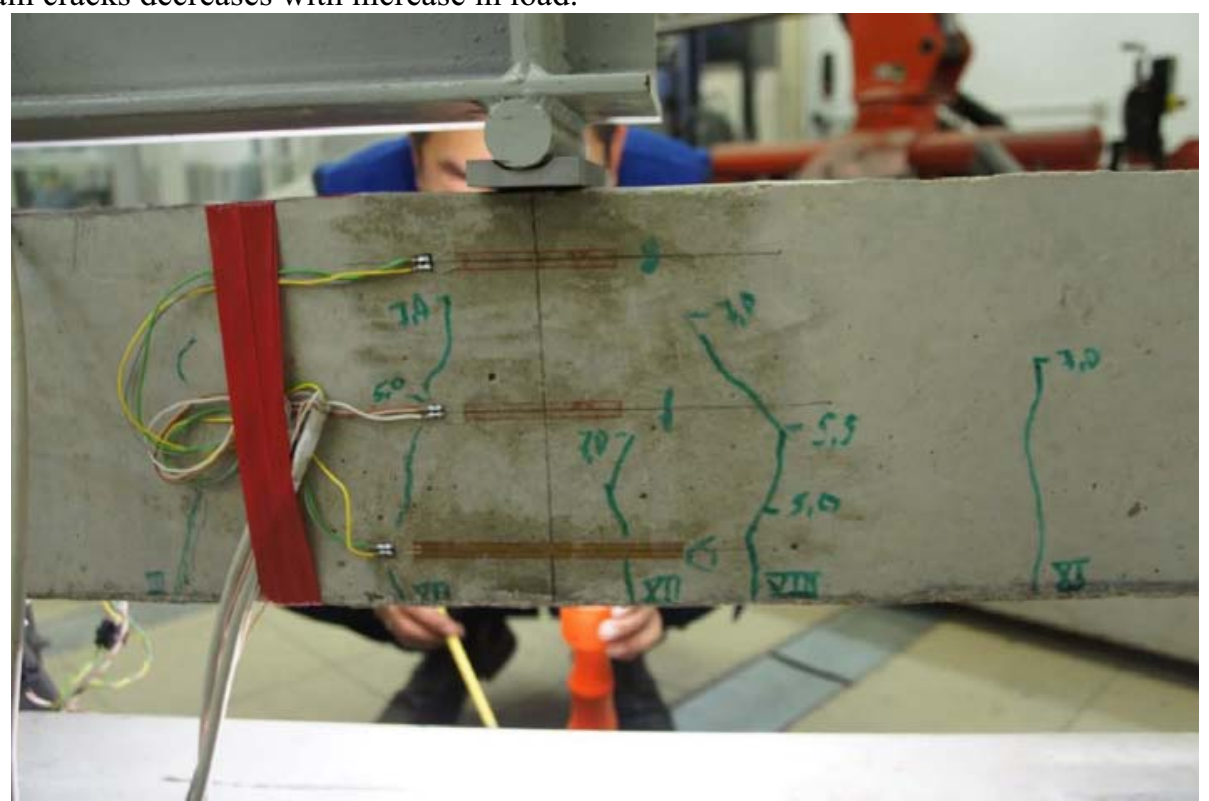

Fig. 2. Crack formation in beam reinforced with GFPR B1.10.1 at load $\mathrm{P}=0,2 \mathrm{P}_{\text {ult }}$

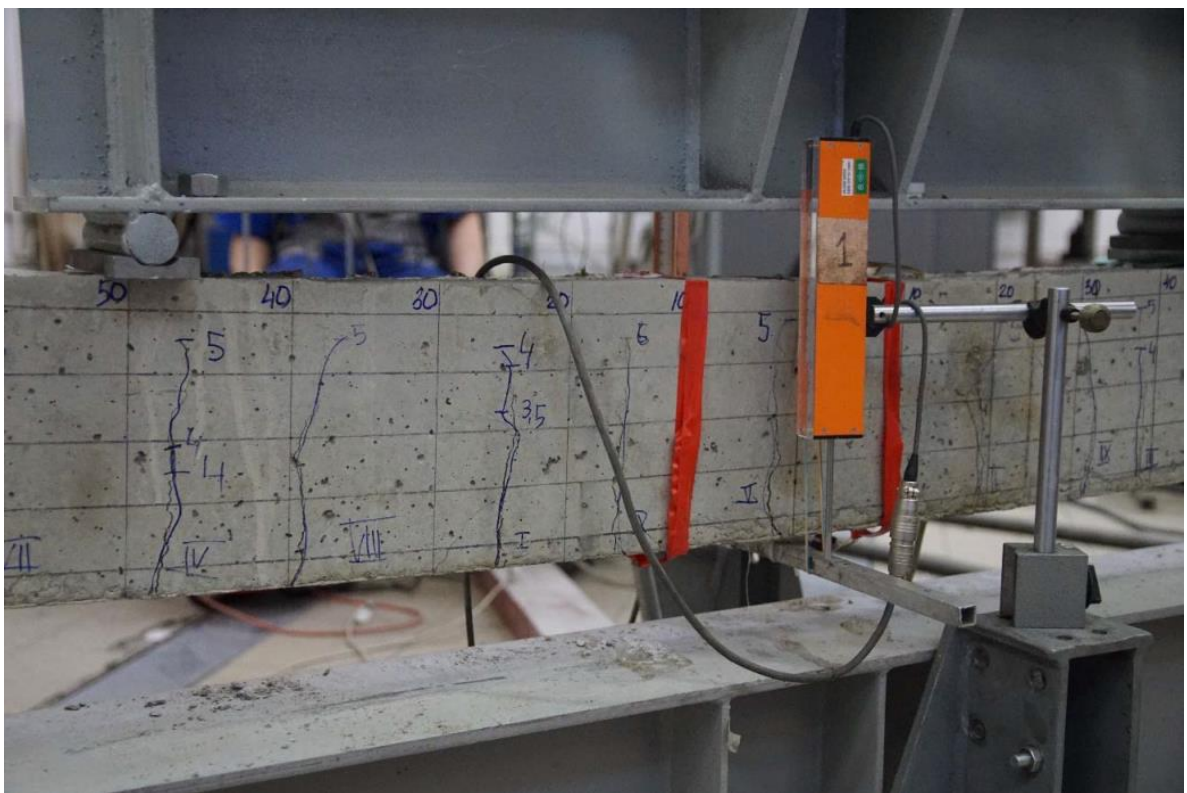

Fig. 3. Crack formation in beam reinforced with $B F P R B 2.6 .3$ at load $P=0,2 P_{\text {ult }}$ 


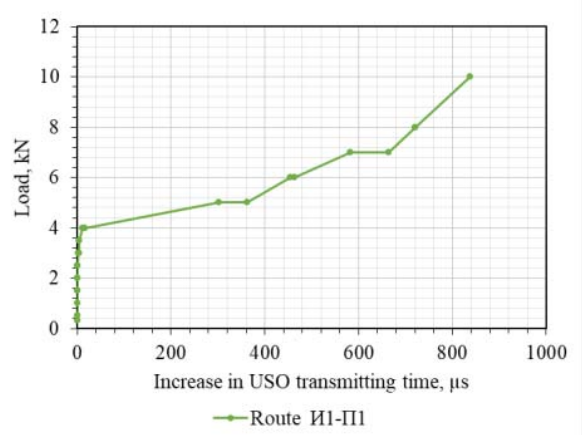

Fig. 4. «Load-increase in USO transmitting time» diagram for beam B1.6.1 with GFRP Ø6 mm

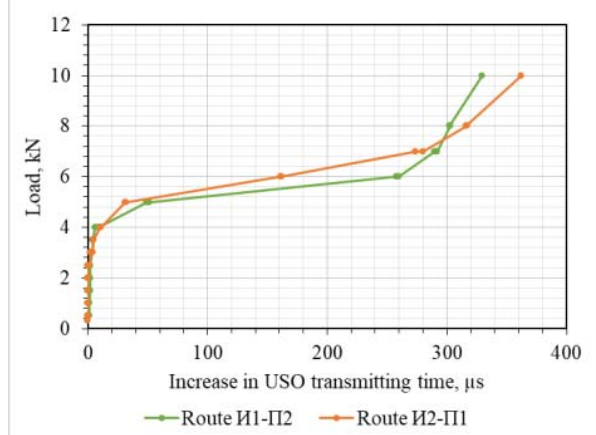

Fig. 5. «Load-increase in USO transmitting time» diagram for beam B1.6.1 with GFRP Ø6 mm

Figure 6, 7 and 8 show strain diagrams for bars and compressive area of concrete for beam B1.6.1.

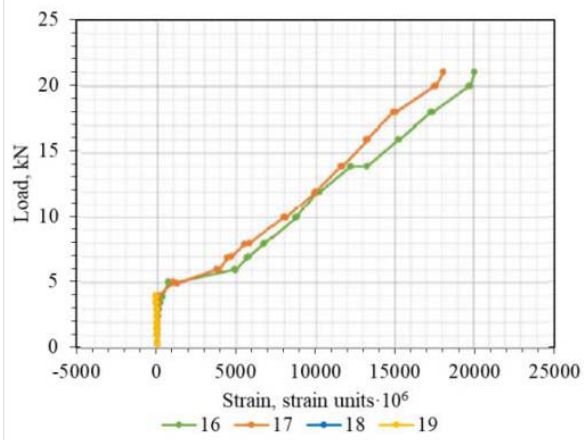

Fig. 6. «Load-strain» diagram for compressive area of concrete for beam B1.6.1 with GFRP Ø6

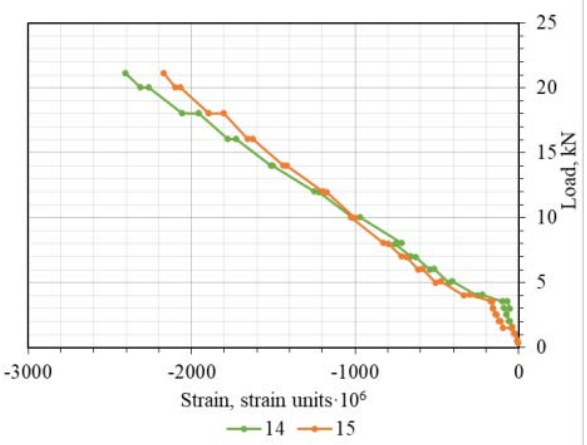

Fig. 7. «Load-strain» diagram for compressive area of concrete for beam B1.6.1 with GFRP Ø6

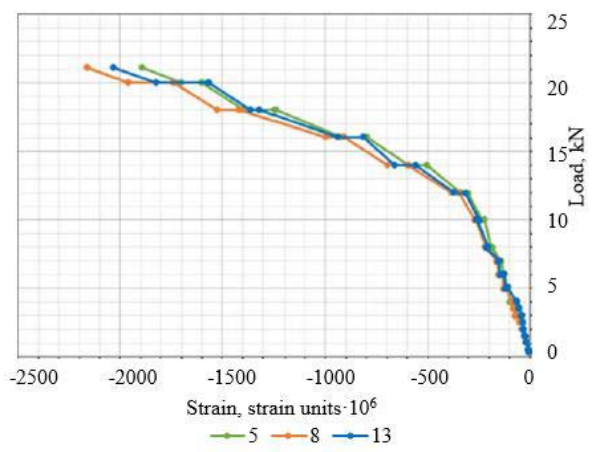

Fig. 8. «Load-strain» diagram for compressive area of concrete for beam B1.6.1 with GFRP Ø6

Relative decrease in bending stiffness and its absolute value on linear straining stage after formation of main cracks were determined from ratio of deflections on $1 \mathrm{kN}$ of load (figures 9, 10, 13, 14, 17 and 18). 


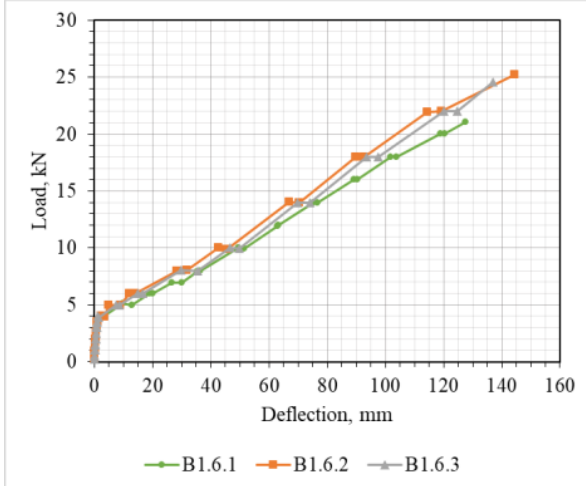

Fig. 9. «Load-deflection» diagram for beams with GFRP Ø6 mm

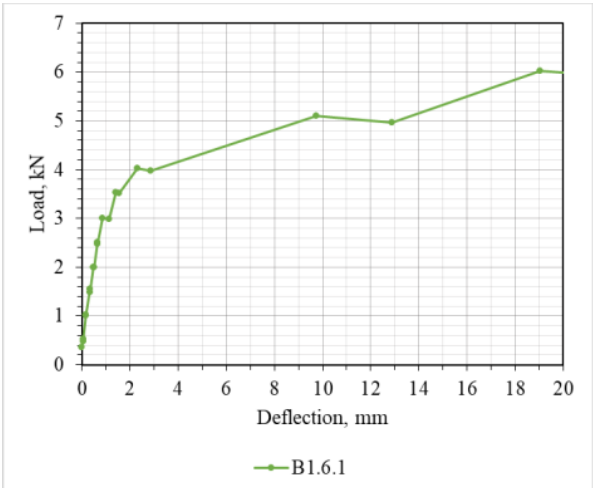

Fig. 11. «Load-deflection» diagram for beam B1.6.1 with GFRP Ø6 mm

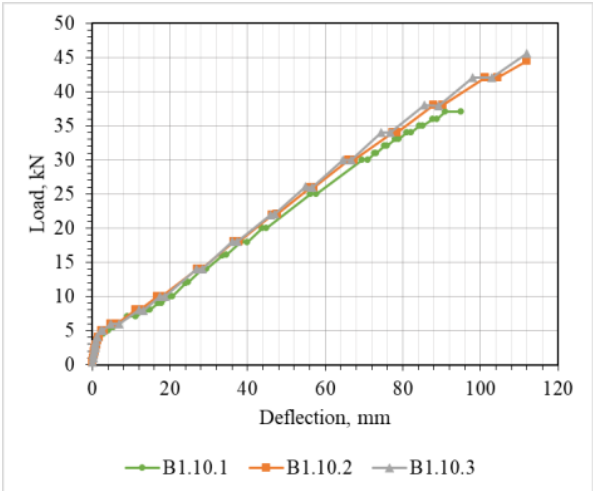

Fig. 13. «Load-deflection» diagram for beams with GFRP $\varnothing 10 \mathrm{~mm}$

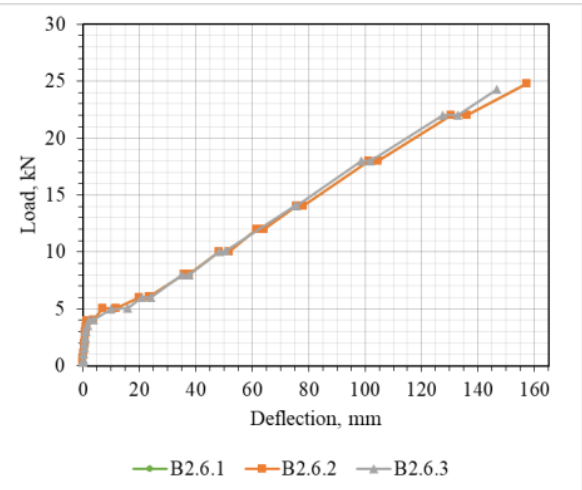

Fig. 10. «Load-deflection» diagram for beams with BFRP Ø6 mm

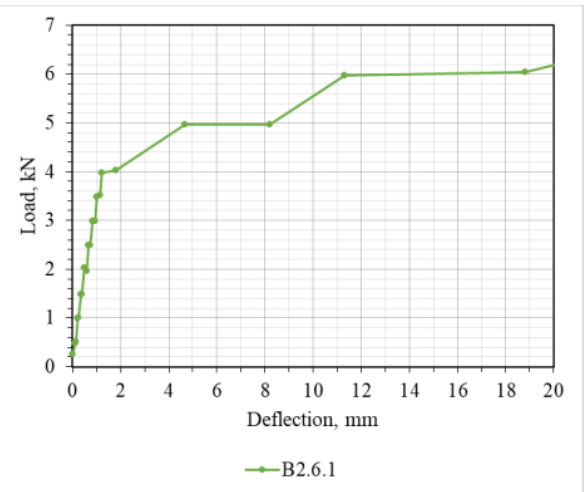

Fig.12. «Load-deflection» diagram for beam B2.6.1 with BFRP Ø6 mm

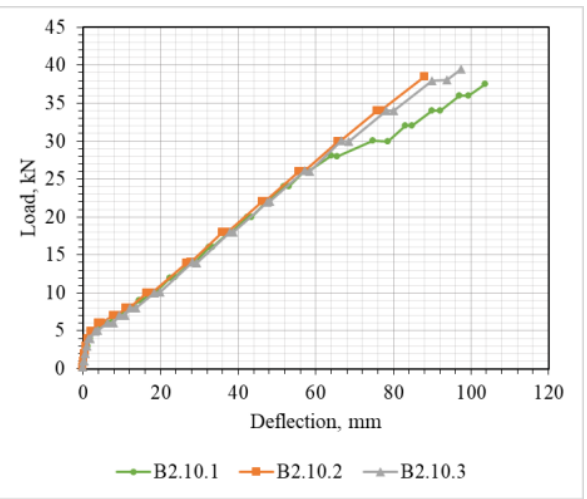

Fig. 14. «Load-deflection» diagram for beams with BFRP $\varnothing 10 \mathrm{~mm}$ 


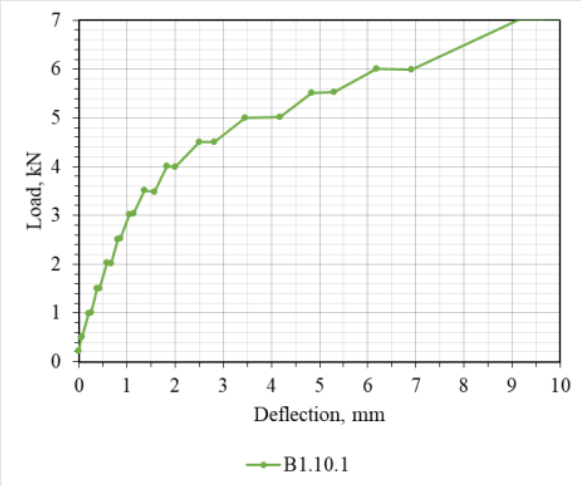

Fig. 15. «Load-deflection» diagram for beam B1.10.1 with GFRP Ø10 mm

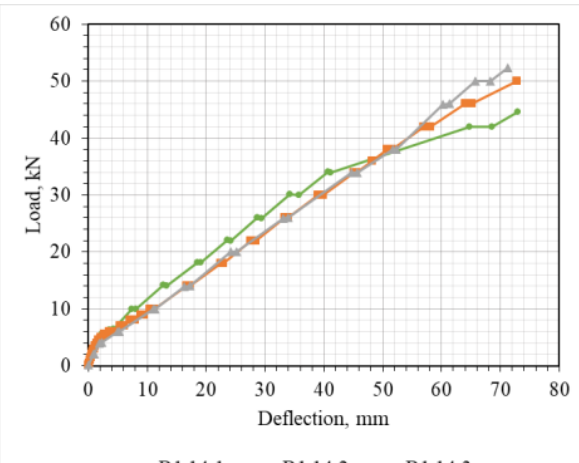

$\rightarrow$ B1.14.1 $-\mathrm{B} 1.14 .2 \rightarrow \mathrm{B} 1.14 .3$

Fig. 17. «Load-deflection» diagram for beams with GFRP Ø14 mm

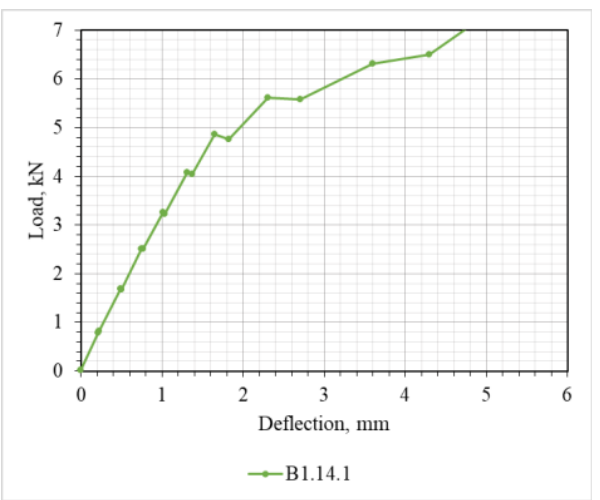

Fig. 19. «Load-deflection» diagram for beam B1.14.1 with GFRP Ø14 mm

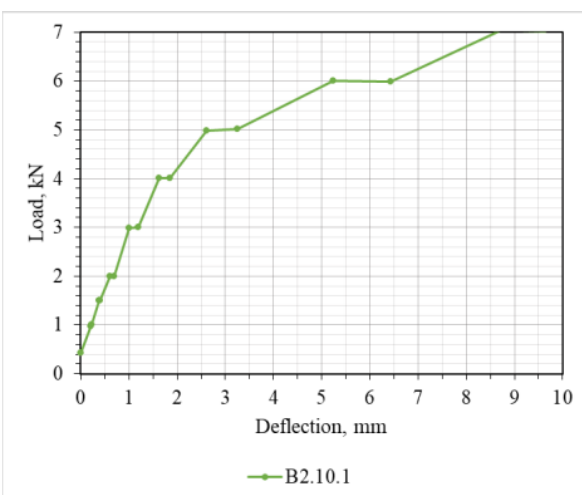

Fig. 16. «Load-deflection» diagram for beam B2.10.1 with BFRP Ø10 mm

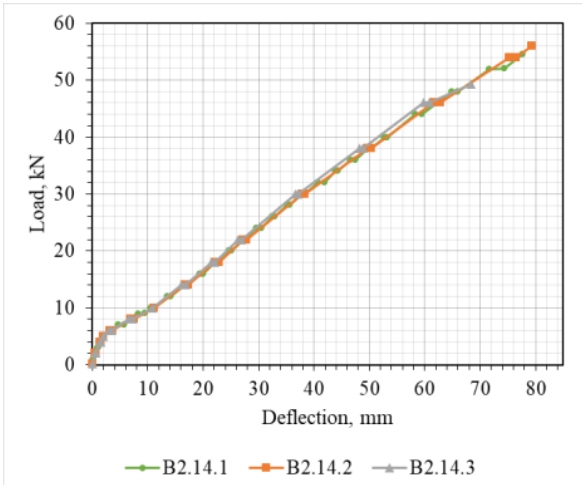

Fig. 18. «Load-deflection» diagram for beams with BFRP $\varnothing 14 \mathrm{~mm}$

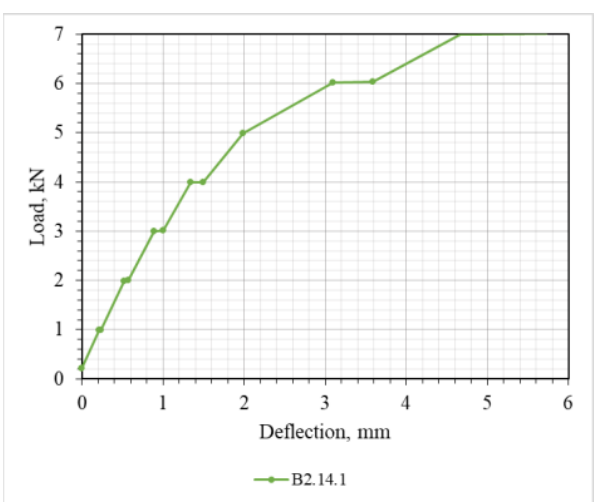

Fig. 20. «Load-deflection» diagram for beam B2.14.1 with BFRP Ø14 mm

\section{Discussions}

Pattern of load-strain relation is typical for all beams reinforced with both GFRP and BFRP. Three straining stages are observed: 1 - collaboration of bars and concrete in tension area; 2 - spasmodic separation of tensile bars from concrete which is most clearly noticed for beams reinforced with bars $6 \mathrm{~mm}$ in diameter; 3 - linear elastic straining of bars and 
concrete on the surface and nonlinear straining in compressive area at depth of $2,5 \mathrm{~cm}$ from top edge. Beams reinforced with GFRP show earlier start of crack formation and smoother transition to linear straining with low bending stiffness compared to beams reinforced with BFRP.

Initial bending stiffness at elastic straining before crack formation (figures 11, 12, 15, 16, 19 and 20) was determined according to design model of pure bending using formula (1):

$$
(E J)_{i}=\frac{23 \cdot P l^{3}}{1296 \cdot f_{\mathrm{H}}}(1)
$$

where $P$ and $f_{u}-$ load and deflection on linear straining stage before crack formation respectively.

Relative decrease in bending stiffness and its absolute value B on linear straining stage after formation of main cracks were determined from ratio of deflections on $1 \mathrm{kN}$ of load (figures 9, 10, 13, 14, 17 and 18). Table 1 shows values of absolute and relative stiffness before and after formation of main cracks.

Table 1. Bending stiffness for beams before and after formation of main cracks

\begin{tabular}{|c|c|c|c|c|c|}
\hline $\begin{array}{c}\text { Beam } \\
\text { with } \\
\text { bars }\end{array}$ & $\begin{array}{l}\text { Bar diameter, } \\
\mathbf{m m}\end{array}$ & $\begin{array}{c}\text { Modulus } \\
\text { of } \\
\text { elasticity } \\
\text { for tension } \\
\mathrm{E}_{\mathrm{a}}, \mathrm{MPa}\end{array}$ & $\begin{array}{c}\text { Initial } \\
\text { stiffness } \\
(\mathbf{E J})_{\mathrm{i}} * 10^{-4} \\
\mathbf{k N}^{*} \mathbf{c m}^{2}\end{array}$ & $\begin{array}{c}\text { Stiffness } \\
\text { after crack } \\
\text { formation } \\
\mathrm{B}^{*} 10^{-4} \\
\mathbf{k N}^{*} \mathbf{c m}^{2}\end{array}$ & $\begin{array}{c}\text { Relative } \\
\text { decrease in } \\
\text { stiffness }\end{array}$ \\
\hline \multirow{3}{*}{ GFRP } & 6 & 63453,43 & 1419,0 & 69,9 & 20,9 \\
\hline & 10 & 59106,12 & 1273,1 & 174,4 & 7,3 \\
\hline & 14 & 52619,05 & 1338,9 & 304,3 & 4,4 \\
\hline \multirow{3}{*}{ BFRP } & 6 & 58827,02 & 1167,1 & 71,6 & 16,3 \\
\hline & 10 & 57541,68 & 1274,3 & 187,4 & 6,8 \\
\hline & 14 & 59299,86 & 1374,7 & 327,3 & 4,2 \\
\hline
\end{tabular}

Disturbance of concrete cover by first cracks occurred after reaching border of elastic straining which was determined by first divergence from linear lo ad-deflection relation. Start of linear area of load-deflection relation on the second loading stage at loads of 80$90 \%$ from beam strength showed formation of main cracks and their transition through reinforcing bars.

\section{Conclusions}

1. Bending stiffness values after crack formation were acquired for two types of FRP of 3 diameters. These values allow to convey calculations for dynamic loading of similar beams and compose test procedure.

2. It was established that remarkable decrease in bending stiffness of beams (for more than 15 times) after main cracks formation is typical for reinforcement with FRP $6 \mathrm{~mm}$ in diameter. Fracture of these beams occurred in reinforcement bars.

3. Insignificant increase of up to 7,5\% was registered on strain stage with cracks for beams reinforced with BFRP bars compared to beams reinforced with GFRP bars.

4. Ultrasonic measurement data shows that qualitative transition from fast formation and growth of main cracks to arrested growth scarcely influence bending stiffness.

\section{References}

1. Antakov A B and Antakov I A 2014 Izvestiya KGASU 29 7-13 
2. Gizdatullin A R, Hozin V G, Kuklin A N and Husnutdinov A M 2014 Inzhenerno stroitelnyj zhurnal 3 40-47

3. Zabegaev A V 1992 Prochnost $i$ deformativnost zhelezobetonnyh konstrukcij pri avarijnyh udarnyh nagruzheniyah dissertatsiya na soiskanie uchenoj stepeni $d t n$ (Moscow: MISI) p 429

4. Kuzevanon D V 2012 Konstrukcii s kompozitnoj nemetallicheskoj armaturoj Obzor $i$ analiz zarubezhnyh i otechestvennyh normativnyh dokumentov (Moscow: NIIZHB)

5. Nikula I 1959 Eksperimentalnye issledovaniya $v$ oblasti primeneniya nemetallicheskoj armatury dlya betona avtoreferat dissertatsii na soiskanie uchenoj stepeni $k t n$ (Moscow: MISI) p 18.

6. Okolnikova G E and Gerasimov S V 2015 Ekologiya i stroitelstvo 3 14-21

7. Plevkov V S, Baldin I V, Kudyakov K L and Nevskij A V 2016 Vestnik TGASU 58 91101

8. Rimshin V I and Merkulov S I 2015 Promyshlennoe i grazhdanskoe stroitelstvo 5 3842

9. Staroverov V D, Baroev R V, Tsurupa A A and Krishtalevich A K 2015 Vestnik grazhdanskih inzhenerov 50 171-178

10. Hismah M, Mailyan D R, Polskoj P P and Blyagoz A M 2012 Novye tehnologii 4 147152

11. GOST 34922013 Armatura kompozitnaya polimernaya dlya armirovaniya betonnyh konstruktsij Metody opredeleniya fiziko mehanicheskih harakteristik

12. SP 29513258002017 Konstruktsii betonnye armirovannye polimernoj kompozitnoj armaturoj Pravila proektirovaniya

13. Goldston M, Remennikov A and Sheikh M.N 2016 Engineering Structures 113220 232

14. Lapko A and Urbanski M 2014 Experimental and theoretical analysis of deflections of concrete beams reinforced with basalt rebar Experimental and theoretical analysis of deflections of concrete beams reinforced with basalt rebar J.ACME.2014.03.008

15. Li V C and Wang S 2002 ACI Materials Journal 99 11-21

16. Qu W, Zhang X and Huang H 2009 ASCE Journal of Composites for Construction 13 350-359

17. Sun Z Y, Wu G, Zhang J, Zeng Y and Xiao W 2017 Construction and building Materials 130 202-211

18. Ghomi S and El-Salakawy E 2019 Engineering Structures 191 583-597

All tests were carried out using research equipment of The Head Regional Shared Research Facilities of the Moscow State University of Civil Engineering. 